\title{
PENGUJIAN TEORI KURVA U-TERBALIK (HIPOTESIS KUZNETS) DI KALIMANTAN BARAT
}

Dely Zulfariska ${ }^{1}$, Nurul Bariyah ${ }^{2}$

${ }^{1}$ Universitas Tanjungpura, Pontianak

${ }^{2}$ Universitas Tanjungpura, Pontianak

Email korespondensi : delyzlf@gmail.com

Abstrak

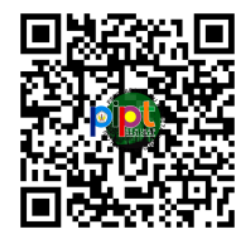

10.26418/pipt.2021.33

\begin{abstract}
Ketimpangan pendapatan masyarakat antar wilayah merupakan satu diantara masalah yang dihadapi dan sering terjadi di negara berkembang termasuk pula di negara Indonesia. Provinsi Kalimantan Barat merupakan satu diantara provinsi yang memiliki tingkat ketimpangan pendapatan masyarakat antar wilayah yang paling tinggi dari empat provinsi yang ada di pulau Kalimantan. Tujuan dari penelitian ini diantaranya 1) Mengklasifikasikan Kabupaten/Kota di Provinsi Kalimantan Barat berdasar pada pertumbuhan ekonomi dan ketimpangan pendapatan masyarakat antar wilayah; 2) Membuktikan Kurva U-Terbalik (Hipotesa Kuznets) berlaku atau tidak di Provinsi Kalimantan Barat; dan 3) Menganalisis pengaruh pertumbuhan ekonomi terhadap ketimpangan pendapatan masyarakat antar wilayah setiap Kabupaten/Kota di Provinsi Kalimantan Barat. Indikator ketimpangan pendapatan masyarakat antar wilayah di Provinsi Kalimantan Barat pada penelitian ini ialah menggunakan angka Gini Rasio. Analisis regresi linier sederhana (GLS) dengan kurun waktu penelitian selama 8 tahun penelitian dari tahun 2011-2018. Penelitian ini menggunakan software Eviews 10. Berdasarkan hasil penelitian dengan menggunakan analisis tipologi klassen bahwa ketimpangan pendapatan masyarakat antar wilayah masih terjadi walau tergolong pada ketimpangan yang sedang. Dalam penelitian ini, berlakunya teori hipotesis Kuznets serta terdapat arah hubungan yang positif dan secara statistik tidak signifikan antara variabel pertumbuhan ekonomi dan ketimpangan pendapatan masyarakat antar wilayah di Provinsi Kalimantan Barat selama periode pengamatan tahun 2011-2018.
\end{abstract}

Kata kunci: ketimpangan, pertumbuhan ekonomi, hipotesis Kuznets

\section{PENDAHULUAN}

Terdapat beberapa tujuan dari pembangunan nasional, diantaranya meningkatkan pendapatan perkapita dan meningkatkan kesejahteraan masyarakat di suatu wilayah (Raswita \& Made, 2013). Keberhasilan pembangunan suatu wilayah dapat diukur dengan pertumbuhan ekonomi dan berkurangnya ketimpangan pendapatan (Amri, 2017), antar penduduk, antar daerah, dan antar sektor (Kurniasih, 2013).

Mirisnya pertumbuhan ekonomi di suatu wilayah tidak dapat menjamin akan berkurangnya tingkat ketimpangan pendapatan di suatu daerah. Jika terlalu menitikberatkan kegiatan ekonomi pada suatu daerah tertentu maka secara langsung akan memberikan dampak pada ketimpangan masyarakat antar daerah, sehingga akan menciptakan kondisi dimana daerah yang menjadi pusat kegiatan ekonomi itulah yang akan memberikan kontribusi pendapatan daerah yang lebih tinggi kepada masyarakatnya. Dengan terjadinya hal yang demikian, maka terciptalah masyarakat yang lebih Makmur. Pada sisi lain, daerah yang tidak menjadi pusat kegiatan ekonomi hanya mampu memberikan pendapatan daerah yang rendah sehingga mengakibatkan relatif rendah pula kemakmuran masyarakatnya (Tambunan, 2014). Dapat ditarik kesimpulan bahwa terdapat hubungan yang negatif antara pertumbuhan ekonomi terhadap ketimpangan pendapatan masyarakat antar wilayah. Artinya semakin tinggi pertumbuhan ekonomi di suatu wilayah maka akan menambah jumlah produksi sehingga output pun meningkat. Peningkatan ini akan berbanding lurus dengan peningkatan pendapatan masyarakat serta pendapatan perkapita juga akan meningkat, kemudian hal ini akan berimbas kepada 
ketimpangan pendapatan masyarakat antar wilayah yang semakin mengecil.

Oleh sebab itu, isu untuk pemerataan ketimpangan pendapatan masyarakat antar wilayah menjadi hal yang patut diperhatikan guna mewujudkan tujuan dari pembangunan nasional, yakni dengan cara peningkatan ketersediaan serta perluasan distribusi barang kebutuhan pokok dalam artian peningkatan output, peningkatan standar hidup masyarakat, baik pada tingkat regional maupun nasional.

Disparitas atau ketimpangan dalam ekonomi dapat diartikan sebagai adanya perbedaan yang sangat nampak antar golongan orang kaya dan orang miskin terutama dalam hal distribusi pendapatan, distribusi kesejahteraan, latar belakang Pendidikan, jenis pekerjaan, tingkat kepuasan dan kebahagiaan hidup (Adrei \& Craciun, 2015). Oleh sebab itu bukan hal yang tabu lagi bilamana di setiap daerah terdapat wilayah maju dan wilayah terbelakang, sama halnya yang terjadi di Pulau Kalimantan terutama pada wilayah Provinsi Kalimantan Barat.

Tabel 1

Rata-rata Pertumbuhan Ekonomi dan Gini Rasio pada Empat Provinsi di Kalimantan Tahun 20112018

\begin{tabular}{|l|c|l|l|}
\hline Provinsi & $\begin{array}{l}\text { Pertumbuha } \\
\text { n Ekonomi } \\
\text { (\%) }\end{array}$ & $\begin{array}{l}\text { Gini } \\
\text { Rasi } \\
\text { o }\end{array}$ & $\begin{array}{l}\text { Pendapata } \\
\text { n/ kapita } \\
\text { (Juta Rp) }\end{array}$ \\
\hline $\begin{array}{l}\text { Kalimanta } \\
\text { n Barat }\end{array}$ & 5,28 & $\begin{array}{l}0,36 \\
1\end{array}$ & 23.235 \\
\hline $\begin{array}{l}\text { Kalimanta } \\
\text { n Timur }\end{array}$ & 1,88 & $\begin{array}{l}0,33 \\
9\end{array}$ & 271,680 \\
\hline $\begin{array}{l}\text { Kalimanta } \\
\text { n Selatan }\end{array}$ & 4,92 & $\begin{array}{l}0,35 \\
1\end{array}$ & 27.536 \\
\hline $\begin{array}{l}\text { Kalimanta } \\
\text { n Tengah }\end{array}$ & 6,53 & $\begin{array}{l}0,34 \\
3\end{array}$ & 31,122 \\
\hline
\end{tabular}

Sumber: BPS, data diolah kembali tahun 2021

Tabel 1 mengenai rata-rata pertumbuhan ekonomi dan gini rasio pada empat Provinsi di Kalimantan tahun 2011 sampai 2018, mengindikasikan bahwa terdapat dua provinsi yang memiliki tingkat pertumbuhan ekonomi rendah namun memiliki ketimpangan yang rendah pula yakni Provinsi Kalimantan Timur dan Kalimantan
Selatan. Pada Provinsi Kalimantan Timur, data menunjukkan masing-masing angka pertumbuhan ekonomi dan gini rasionya adalah $1,88 \%$ dan 0,339 . Sedangkan pada Provinsi Kalimantan Selatan, data menunjukkan masing-masing angka pertumbuhan ekonomi dan gini rasionya adalah $4,92 \%$ dan 0,351. Kemudian terdapat provinsi yang memiliki tingkat pertumbuhan ekonomi yang paling tinggi dari ketiga provinsi di pulau Kalimantan namun memiliki ketimpangan yang terendah kedua yaitu provinsi Kalimantan Tengah, data menunjukkan masing-masing angka pertumbuhan ekonomi dan gini rasionya adalah $6,53 \%$ dan 0,343. Hal ini mengindikasikan bahwa kesejahteraan masyarakat pada ketiga provinsi tersebut relatif baik.

Sedangkan pada Provinsi Kalimantan Barat memiliki tingkat pertumbuhan ekonomi tertinggi kedua setelah Kalimantan Tengah serta memiliki tingkat ketimpangan yang paling tinggi pula dari ketiga provinsi tersebut, data menunjukkan masing-masing angka pertumbuhan ekonomi dan gini rasionya adalah $5,28 \%$ dan 0,361 . Artinya pada provinsi Kalimantan Barat mencerminkan distribusi pendapatan yang tidak merata yang mengindikasikan bahwa kesejahteraan masyarakatnya kurang baik dibandingkan dari ketiga Provinsi di Pulau Kalimantan.

Terdapat lima peneliti melakukan penelitian yang berkaitan pula dengan pertumbuhan ekonomi dan ketimpangan antar wilayah pada level Kabupaten/Kota yaitu Yuliani (2015) dan Kurniasih (2013) dan level Provinsi yaitu Amri (2017) dan Islami (2018). Hal inilah yang melatarbelakangi penulis untuk meneliti lebih lanjut pada Provinsi Kalimantan Barat. Penjelasan lebih lanjut mengenai ketimpangan di Provinsi Kalimantan Barat akan dijelaskan pada tabel 2 .

Tabel 2

Gini rasio PDRB Provinsi Kalimantan Barat periode 2011-2018 


\begin{tabular}{|c|c|c|c|c|}
\hline $\begin{array}{l}\text { Tah } \\
\text { un }\end{array}$ & $\begin{array}{l}\text { Gin } \\
\text { i } \\
\text { Ras } \\
\text { io }\end{array}$ & $\begin{array}{l}\text { Pertumb } \\
\text { uhan } \\
(\%)\end{array}$ & $\begin{array}{l}\text { Pendapat } \\
\text { an (Juta } \\
\text { Rp) }\end{array}$ & $\begin{array}{l}\text { Pertumb } \\
\text { uhan } \\
(\%)\end{array}$ \\
\hline $\begin{array}{l}201 \\
1\end{array}$ & $\begin{array}{l}0,3 \\
82\end{array}$ & & $\begin{array}{l}\text { Rp } \\
90.797 .59 \\
0,93\end{array}$ & - \\
\hline $\begin{array}{l}201 \\
2\end{array}$ & $\begin{array}{l}0,3 \\
88\end{array}$ & 1,571 & $\begin{array}{l}\mathrm{Rp} \\
96.161 .92 \\
8,39\end{array}$ & 5,91 \\
\hline $\begin{array}{l}201 \\
3\end{array}$ & $\begin{array}{l}0,3 \\
90\end{array}$ & 0,515 & $\begin{array}{l}\text { Rp } \\
101.980 .3 \\
39,36\end{array}$ & 6,05 \\
\hline $\begin{array}{l}201 \\
4\end{array}$ & $\begin{array}{l}0,3 \\
97\end{array}$ & 1,667 & $\begin{array}{l}\mathrm{Rp} \\
107.114 .9 \\
62,94\end{array}$ & 5,03 \\
\hline $\begin{array}{l}201 \\
5\end{array}$ & $\begin{array}{l}0,3 \\
32\end{array}$ & 16,267 & $\begin{array}{l}\text { Rp } \\
112.346 .7 \\
55,19\end{array}$ & 4,88 \\
\hline $\begin{array}{l}201 \\
6\end{array}$ & $\begin{array}{l}0,3 \\
36\end{array}$ & 1,205 & $\begin{array}{l}\mathrm{Rp} \\
118.193 .4 \\
31,56\end{array}$ & 5,20 \\
\hline $\begin{array}{l}201 \\
7\end{array}$ & $\begin{array}{l}0,3 \\
28\end{array}$ & $-2,381$ & $\begin{array}{c}\mathrm{Rp} \\
124.289 .1 \\
72,16\end{array}$ & 5,16 \\
\hline $\begin{array}{l}201 \\
8\end{array}$ & $\begin{array}{l}0,3 \\
32\end{array}$ & 1,220 & $\begin{array}{l}\text { Rp } \\
130.589 .0 \\
22,90\end{array}$ & 5,07 \\
\hline
\end{tabular}

Sumber: BPS, data diolah kembali tahun 2021

Berdasarkan pada tabel 2 bahwa koefisien gini rasio di Provinsi Kalimantan Barat menunjukkan angka yang turun naik atau berfluktuatif selama 8 tahun terakhir. Angka yang terlampir di data tersebut mengindikasikan bahwa adanya ketimpangan di setiap tahunnya. Dari tahun 2011 sampai dengan 2014 koefisien gini rasio di Kalimantan Barat mengalami kenaikan di setiap tahunnya. Pada tahun 2014 angka gini rasionya sangat tinggi, yakni 0,397. Kemudian pada tahun 2015 angka gini rasio di kalimantan barat mengalami penurunan yang sangat drastis sehingga pertumbuhan gini rasionya menjadi $16.27 \%$ atau mengalami penurunan sebesar 0,065 poin. Pada tahun 2016 naik kembali sebesar 0,004 poin atau mengalami kenaikan pertumbuhan gini rasio sebesar $1,20 \%$. Kemudian turun kembali pada tahun 2017 sebesar 0,008 poin atau mengalami penurunan pertumbuhan gini rasio sebesar
2,38\%. Kemudian naik kembali pada tahun 2018 sebesar 0,004 poin atau mengalami kenaikan pertumbuhan gini rasio sebesar $1.22 \%$. Dapat ditarik kesimpulan bahwa, naik turunnya angka gini rasio yang terjadi di Provinsi Kalimantan Barat pada tahun 2011-2018 atau selama 8 tahun terakhir masih dapat diklasifikasikan pada tingkat ketimpangan pendapatan yang relatif sedang.

Fenomena pertumbuhan ekonomi Provinsi Kalimantan Barat yang terjadi pada tahun 2011 sampai dengan 2013 menunjukkan tren yang meningkat di setiap tahunnya. Tingkat pertumbuhan ekonomi yang paling tinggi selama 8 tahun terakhir terjadi pada tahun 2013 yakni dengan tingkat pertumbuhan ekonomi sebesar 6,05\%. Kemudian dimulai dari tahun 2014 menunjukkan tren pertumbuhan ekonomi yang menurun dari tahun sebelumnya, yakni dengan tingkat pertumbuhan ekonomi sebesar $5,03 \%$. Selanjutnya tahun 20152016 menunjukkan tren peningkatan pertumbuhan sekaligus kesenjangan pendapatan yang relatif meningkat. Pada tahun 2016-2017 menunjukkan tren penurunan pertumbuhan sekaligus kesenjangan pendapatan yang relatif menurun pula. Pada tahun 2017-2018 menunjukkan tren penurunan pertumbuhan sekaligus kesenjangan pendapatan yang relatif meningkat. Dapat disimpulkan bahwa, hal ini mengindikasikan di Provinsi Kalimantan Barat mengalami fenomena kesejahteraan masyarakat yang belum merata.

Tabel 3

Rata-rata Pertumbuhan Ekonomi dan Pendapatan per Kapita Menurut Kabupaten/Kota di Provinsi Kalimantan Barat Tahun 2011-2018

\begin{tabular}{|l|c|l|}
\hline $\begin{array}{l}\text { Kabupaten / } \\
\text { Kota }\end{array}$ & $\begin{array}{l}\text { Pertumbuahan } \\
\text { Ekonomi (\%) }\end{array}$ & $\begin{array}{l}\text { Pendapatan } \\
\text { / Kapita } \\
\text { (Juta Rp) }\end{array}$ \\
\hline Sambas & 6,25 & 20,751 \\
\hline Bengkayang & 5,14 & 19,463 \\
\hline Landak & 5,18 & 15,926 \\
\hline Mempawah & 5,51 & 16,401 \\
\hline Sanggau & 4,75 & 24,738 \\
\hline
\end{tabular}




\begin{tabular}{|l|c|l|}
\hline $\begin{array}{l}\text { Kabupaten / } \\
\text { Kota }\end{array}$ & $\begin{array}{l}\text { Pertumbuahan } \\
\text { Ekonomi (\%) }\end{array}$ & $\begin{array}{l}\text { Pendapatan } \\
\text { I Kapita } \\
\text { (Juta Rp) }\end{array}$ \\
\hline Ketapang & 5,83 & 28,924 \\
\hline Sintang & 5,44 & 19,505 \\
\hline Kapuas Hulu & 4,93 & 21,498 \\
\hline Sekadau & 6,03 & 17,422 \\
\hline Melawi & 5,07 & 14,187 \\
\hline $\begin{array}{l}\text { Kayong } \\
\text { Utara }\end{array}$ & 5,45 & 19,376 \\
\hline $\begin{array}{l}\text { Kota } \\
\text { Pontianak }\end{array}$ & 6,31 & 26,094 \\
\hline $\begin{array}{l}\text { Kota } \\
\text { Singkawang }\end{array}$ & 5,90 & 33,407 \\
\hline $\begin{array}{l}\text { Kalimantan } \\
\text { Barat }\end{array}$ & 5,90 & 26,555 \\
\hline
\end{tabular}

Sumber: BPS, data diolah kembali tahun 2021

Berdasar Tabel 3 bahwa terdapat wilayah dengan pertumbuhan ekonominya rendah daripada provinsi yang faktanya memiliki pendapatan perkapita yang tinggi seperti Kabupaten Sanggau. Kemudian didapati wilayah yang pertumbuhan ekonomi tinggi namun terdapat pendapatan perkapita rendah, adapun kabupaten yang dimaksud ialah Kabupaten Sambas dan Kabupaten Sekadau.

Secara keseluruhan, pendapatan perkapita antar daerah di Provinsi Kalimantan Barat tergolong rendah, dan hanya tiga Kabupaten/Kota saja yang pendapatan perkapitanya relatif lebih baik dari Kabupaten/Kota lain. Secara data, hal ini menggambarkan kesejahteraan masyarakat daerah perkotaan di Provinsi Kalimantan Barat relatif lebih baik sehingga menyebabkan adanya perbedaan PDRB antar daerah yang menunjukkan jurang ketimpangan pembangunan yang semakin jauh dan berakibat pada tingkat kesejahteraan masyarakat pun memiliki jurang ketimpangan yang dalam.

Berdasarkan latar belakang masalah yang telah disampaikan di atas, permasalahan pada penelitian kali ini ialah Provinsi Kalimantan Barat merupakan satu diantara provinsi di Indonesia khususnya di pulau Kalimantan dengan pertumbuhan ekonomi yang relatif rendah. Berdasarkan pada data table 3, yakni perbedaan nilai
PDRB dan laju PDRB (Pertumbuhan ekonomi dalam persen (\%)) antar daerah, yang dampaknya terhadap perbedaan tingkat kesejahteraan antar daerah, dan pada akhirnya akan menyebabkan jurang ketimpangan antar wilayah yang semakin melebar serta dapat menghambat pembangunan ekonomi daerah. Jika ditinjau dari hipotesis Kuznets, pertumbuhan ekonomi yang diikuti oleh ketimpangan hanya terjadi pada tahap awal pembangunan dan kemudian apabila telah sampai pada tahap titik puncaknya maka ketimpangan tersebut akan menurun, sehingga jika digambarkan dalam bentuk kurva akan seperti huruf U-terbalik.

Berdasarkan kesimpulan dari masalah yang telah dipaparkan pada latar belakang, maka terdapat tiga pertanyaan dalam penelitian ini, yaitu:

1. Bagaimana kondisi Kabupaten/Kota di Provinsi Kalimantan Barat berdasar pada pertumbuhan ekonomi dan ketimpangan pendapatan masyarakat antar wilayah?

2. Apakah Kurva U-Terbalik (Hipotesa Kuznets) berlaku di Provinsi Kalimantan Barat?

3. Apakah pertumbuhan ekonomi memiliki pengaruh terhadap ketimpangan pendapatan masyarakat antar wilayah Kabupaten/Kota di Provinsi Kalimantan Barat?

Tujuan dalam penelitian ini untuk melihat ketimpangan pendapatan masyarakat antar wilayah yang sedang berlangsung di Kalimantan Barat. Lebih spesifiknya, penelitian ini berfokus pada tiga tujuan utama, yakni:

1. Mengklasifikasikan Kabupaten/Kota di Provinsi Kalimantan Barat berdasar pada pertumbuhan ekonomi dan ketimpangan pendapatan masyarakat antar wilayah;

2. Membuktikan Kurva U-Terbalik (Hipotesa Kuznets) berlaku atau tidak di Provinsi Kalimantan Barat; dan

3. Menganalisis pengaruh pertumbuhan ekonomi terhadap ketimpangan 
pendapatan masyarakat antar wilayah setiap Kabupaten/Kota di Provinsi Kalimantan Barat.

\section{KAJIAN LITERATUR}

\section{a. Pertumbuhan Ekonomi}

Membahas teori pertumbuhan ekonomi dalam penelitian kali ini dianggap penting karena akan menganalisa perkembangan ekonomi di suatu wilayah. Hal ini disebabkan teori pertumbuhan ekonomi itu sendiri akan berimplikasi pada pengambilan kebijakan guna mencapai pemerataan pembangunan di suatu wilayah.

Kuznet dalam Todaro (2012) menyatakan bahwa pertumbuhan ekonomi dapat diartikan sebagai adanya peningkatan output yang didukung oleh adanya kemajuan serta penyesuaian dalam faktor produksi seperti teknologi, institusi, dan ideologis berdasarkan situasi dan kondisi di suatu wilayah. Selain itu bahwa akumulasi modal, pertumbuhan penduduk, dan kemajuan teknologi adalah tiga faktor yang mempengaruhi dalam pertumbuhan ekonomi di setiap negara.

Berdasarkan pemaparan mengenai pertumbuhan ekonomi di atas, ialah jika adanya peningkatan output, maka hal ini dimaksudkan agar pendapatan masyarakat dan pendapatan perkapita juga meningkat sehingga berpengaruh terhadap pemerataan distribusi pendapatan dan diharapkan adanya peningkatan kesejahteraan masyarakat di suatu wilayah sehingga tercapainya pemerataan pembangunan di suatu wilayah.

Satu diantara indikator untuk mengetahui kondisi perekonomian suatu wilayah pada periode tertentu dapat dilihat melalui Pendapatan Domestik Regional Bruto (PDRB), baik dihitung berdasarkan atas dasar harga berlaku maupun atas dasar harga konstan. PDRB atas dasar harga berlaku mengindikasikan adanya nilai tambah barang dan jasa yang dihitung menggunakan harga pada periode saat ini, sedangkan PDRB atas dasar harga konstan mengindikasikan adanya nilai tambah dari barang dan jasa yang dihitung berdasarkan harga yang berlaku pada satu tahun tertentu sebagai tahun dasar.

PDRB dihitung berdasarkan pada tiga pendekatan, yakni: Produksi (Lapangan Usaha), Pendapatan, dan Pengeluaran (Penggunaan). Ketiganya akan memberikan kuantitas serupa antara kuantitas output dan input (barang dan jasa) akhir yang diperoleh, serta wajib serupa antara kuantitas pendapatan faktor-faktor produksinya (Bank Indonesia, 2015).

\section{b. Ketimpangan Pendapatan Masyarakat antar Wilayah}

Ketimpangan ekonomi dapat diartikan sebagai adanya gap antar golongan kaya dan golongan miskin dalam hal pendistribusian pendapatan, kekayaan, pendidikan, pekerjaan, kebahagiaan dan kesejahteraan di suatu wilayah (Adrei \& Craciun, 2015).

Ketimpangan pendapatan masyarakat antar wilayah memiliki kaitan yang erat dengan distribusi pendapatan masyarakat di suatu wilayah. Semakin tingginya tingkat ketimpangan pendapatan masyarakat antar wilayah mengindikasikan semakin tinggi pula tingkat ketidakmerataan pendapatan. Artinya kesenjangan pendapatan antar masyarakat golongan kaya dan miskin juga semakin tampak di suatu daerah.

Adelman dan Moris (1973) menyatakan bahwa penyebab dari ketimpangan pendapatan di negara berkembang karena adanya peningkatan jumlah penduduk yang semakin bertambah sehingga berdampak pada menurun pula pendapatan perkapita di suatu negara. Faktor lain yang menyebabkan ketimpangan ini adalah inflasi yang disebabkan oleh pendapatan yang bertambah tetapi tidak diimbangi dengan pertambahan produksi barang yang dampak akhirnya pengangguran bertambah, rendahnya mobilitas sosial, dan lain-lain (Arsyad, 2004).

Satu diantara indikator untuk melihat tingkat ketimpangan pendapatan masyarakat antar wilayah dapat dilihat dengan Gini Rasio yang dijadikan sebagai indikator dalam mengukur distribusi pendapatan antar golongan masyarakat di suatu daerah 
(Sjafrizal, 2012). Gini rasio merupakan ukuran ketimpangan pendapatan secara agregat atau secara keseluruhan yang ditunjukkan dengan angka 0-1. Nol artinya pemerataan sempurna dan satu adalah ketimpangan sempurna.

\section{c. Hubungan Pertumbuhan Ekonomi dan Ketimpangan Pendapatan Masyarakat antar Wilayah}

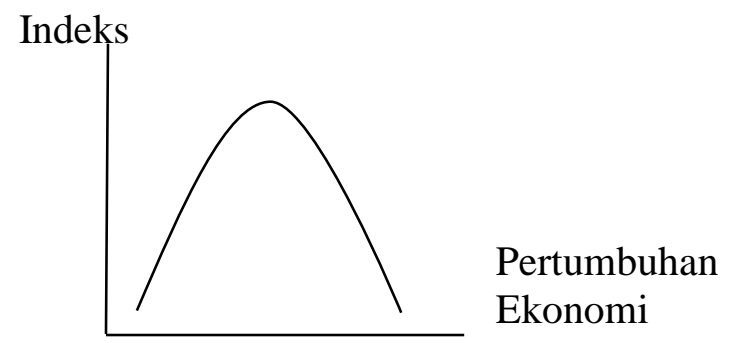

Gambar 1

Kurva U-Terbalik Kuznets

Kuznets (1955) menemukan bahwa terdapat korelasi antara pertumbuhan ekonomi dan tingkat ketimpangan pembangunan. Ia menyatakan bahwa hubungan keduanya dapat dinyatakan seperti gambar kurva Uterbalik. Kurva tersebut mempresentasikan dalam waktu yang minim korelasi antara pertumbuhan ekonomi dan ketimpangan pembangunan bersifat positif yang ditandai dengan grafik yang meningkat. Kemudian jika sudah mencapai titik klimaks atau titik maksimumnya, maka dalam waktu yang cukup lama korelasi antara pertumbuhan ekonomi dan ketimpangan pembangunan bersifat negatif yang ditandai dengan grafik yang menurun. Penyebab dari naik nya pada fase awal pertumbuhan ekonomi ini adalah terjadinya urbanisasi dan industrialisasi.

Kemudian hipotesis Kuznets ini diteliti lagi keabsahannya oleh Williamson tahun 1966. Dalam penelitiannya ia melihat masalah tingkat ketimpangan pembangunan yang terjadi pada wilayah negara modern dan negara terbilang tradisional dengan menggunakan data time series dan crosssection. Fakta empiris dari penelitian yang dilakukan Williamson ini mendukung teori yang disampaikan oleh Kuznets sebelumnya, yaitu pada awal pembangunan di suatu wilayah akan menunjukkan tingkat ketimpangan yang semakin lebar, jika sudah mencapai pada titik maksimum maka akan berlaku sebaliknya.

\subsection{Kajian Empiris}

Yuliani (2015) menunjukkan bahwa terdapat korelasi yang negatif antara pertumbuhan ekonomi dan ketimpangan pembangunan di Kalimantan Timur tahun 2010-2012. Menurut hasil analisis dengan menggunakan Indeks Williamson selama penelitian yang ia lakukan menunjukkan tren yang berfluktuatif. Sedangkan pada tingkat ketimpangan pendapatan menunjukkan angka yang semakin mengecil artinya distribusi pendapatan semakin merata dari tahun ke tahun yang dianalisis dengan menggunakan indeks Entropy Theil. Penelitian yang dilakukan oleh Yuliani ini sangat relevan dengan tujuan yang akan dilakukan oleh penulis terutama dalam hal menganalisis Ketimpangan Pendapatan dan pengujian teori kurva U-terbalik di Provinsi Kalimantan Barat.

Selanjutnya penelitian yang dilakukan oleh Kurniasih (2013) menunjukkan hubungan yang negatif antara pertumbuhan ekonomi dengan ketimpangan wilayah di Provinsi Kalimantan Barat tahun 2001-2010. Menurut hasil analisis dengan menggunakan Indeks Williamson selama periode penelitian yang dilakukannya, menunjukkan tingkat ketimpangan wilayah antar Kabupaten/Kota di Kalimantan Barat relatif rendah, artinya tercapai pula kemerataan pada pendapatan perkapita di wilayah tersebut. Oleh karena nilai Indeks Williamson pada tahun 2001-2010 cenderung menurun sedangkan pertumbuhan ekonominya meningkat, hal inilah yang melatarbelakangi tidak berlakunya Hipotesis Kuznets di Provinsi Kalimantan Barat dari tahun 2001-2010. Penelitian yang dilakukan oleh Kurniasih ini sangat relevan pula untuk menjawab tujuan penelitian yang akan dilakukan penulis terutama dalam hal menganalisis pengujian teori kurva Uterbalik di Provinsi Kalimantan Barat. 
Kemudian Amri (2017) juga membuktikan adanya hubungan yang negatif antar ketimpangan pendapatan terhadap pertumbuhan ekonomi yang menggunakan data panel di delapan (8) provinsi daerah Sumatera dari tahun 2007-2015. Secara mendalam, penelitian yang dilakukan Amir ini ingin melihat keterkaitan antar hubungan kedua variabel yakni Ketimpangan Pendapatan dan Pertumbuhan Ekonomi. Dengan menggunakan granger causality test ia menemukan kausalitas satu arah, yang dimana hanya ketimpangan pendapatan saja yang berpengaruh terhadap pertumbuhan ekonomi, tidak dengan sebaliknya. Penelitian ini sangat relevan dalam hal melihat cara yang dipakai untuk menganalisis pengaruh pertumbuhan ekonomi terhadap ketimpangan pembangunan antar wilayah setiap Kabupaten/Kota di Provinsi Kalimantan Barat.

Kemudian Islami (2018) dalam penelitiannya ingin melihat faktor-faktor yang mempengaruhi ketimpangan wilayah di provinsi Jawa Timur dari tahun 2001 sampai dengan 2015. Dalam penelitiannya ini indeks ketimpangan wilayah dihitung dengan Indeks Williamson. Hasil penelitiannya menunjukkan tren yang berfluktuatif dan cenderung meningkat karena nilai yang dihasilkan sangat tinggi yakni mendekati angka 1 selama periode penelitian. Variabel pertumbuhan ekonomi memiliki pengaruh negatif dan tidak signifikan, variabel I memiliki hubungan negatif dan signifikan dan variabel IPM memiliki hubungan positif dan tidak signifikan. Penelitian yang dilakukan Islami ini sangat relevan dengan penulisan yang akan dilakukan oleh peneliti dalam hal melihat bagaimana hubungan antara ketimpangan pendapatan masyarakat antar daerah di Provinsi Kalimantan Barat.

Penelitian yang dilakukan oleh Alin, Heribertga, \& Umiyati (2019) menunjukkan bahwa terdapat hubungan yang negatif antara pertumbuhan ekonomi dan ketimpangan pendapatan masyarakat antar daerah di Provinsi Jambi yakni dengan menggunakak indeks gini dari tahun 2001 hingga 2016. Namun pada sebelas Kabupaten/Kota di Provinsi Jambi dari tahun 2011 hingga 2016 hanya Kabupaten Sungai Penuh saja yang menunjukkan hubungan positif antara pertumbuhan ekonomi dan ketimpangan pendapatan masyarakat antar daerah di Provinsi Jambi. Hasil penelitian ini tidak terbuktinya Kurva U-terbalik sehingga tidak berlakunya hipotesis Kuznets di Provinsi Jambi serta di tiap-tiap Kabupaten/Kota di Provinsi Jambi. Penelitian yang dilakukan oleh Alin, Heribertga, \& Umiyati (2019) ini sangat relevan dengan tujuan yang akan dilakukan oleh penulis terutama dalam hal terbukti atau tidaknya Kurva U-terbalik di Provinsi Kalimantan Barat.

\subsection{Kerangka Konseptual}

Dua variabel yang digunakan dalam penelitian ini adalah pertumbuhan ekonomi dan ketimpangan pendapatan masyarakat antar wilayah. Variabel ketimpangan pendapatan masyarakat antar wilayah dipengaruhi oleh variabel pertumbuhan ekonomi.

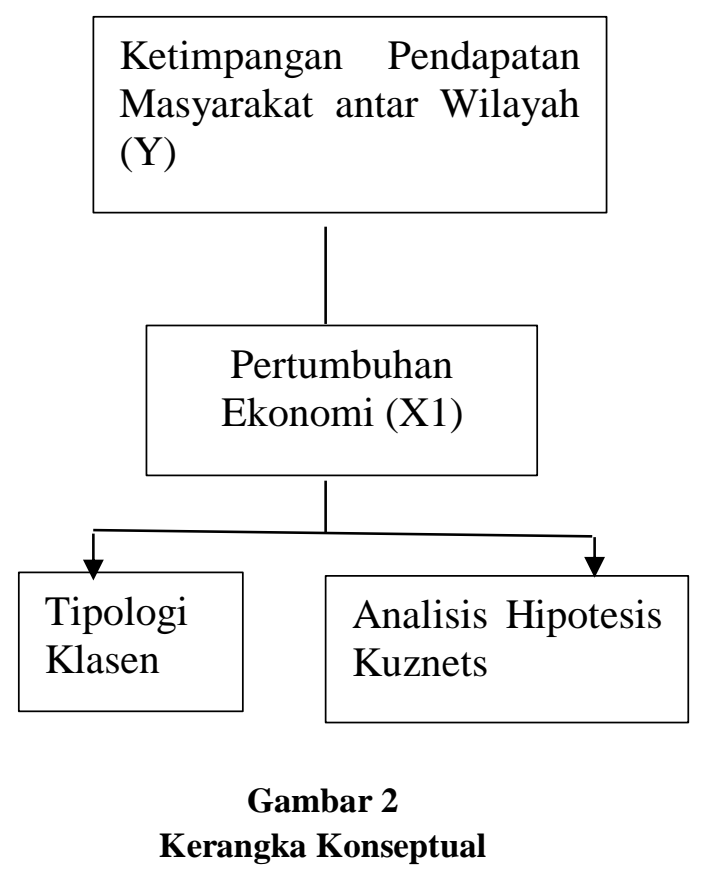

Berdasarkan kerangka konseptual di atas gambar 2, Fungsi kerangka konseptual pada penelitian ini merupakan gambaran ringkas mengenai arah untuk mempermudah 
penelitian. terdapat Tipologi Klasen yang digunakan untuk mengklasifikasikan Kabupaten/Kota di Provinsi Kalimantan Barat berdasar pada pertumbuhan ekonomi dan ketimpangan pembangunan antar daerah. Selanjutnya Gini Rasio akan digunakan sebagai indikator ketimpangan pendapatan masyarakat antar wilayah yang akan digunakan untuk menganalisis Hipotesis Kuznets guna mengetahui berlaku atau tidaknya teori U-terbalik (Hipotesis Kuznets) yang mengindikasikan adanya hubungan antara pertumbuhan ekonomi dengan ketimpangan pembangunan yang terjadi di Provinsi Kalimantan Barat.

\subsection{Hipotesis Penelitian}

Berlandaskan pada teori serta hasil penelitian terdahulu, maka hipotesis penelitian ini adalah sebagai berikut:

1. Diduga ketimpangan pendapatan masyarakat antar wilayah yang terjadi antar wilayah Kabupaten/Kota di Provinsi Kalimantan Barat sangat lebar.

2. Diduga hipotesis Kuznets mengenai teori U-terbalik tidak terbukti di Provinsi Kalimantan Barat.

\section{METODOLOGI}

Bentuk penelitian pada pengujian teori Kurva U-Terbalik (Hipotesis Kuznets) di Provinsi Kalimantan Barat ini bersifat kuantitatif. Menurut Creswell \& Poth (2016) metode penelitian yang bersifat kuantitatif ialah satu diantara cara untuk menguji teoriteori tertentu dengan cara meneliti hubungan antar variabel.

Jenis data yang digunakan pada penelitian ini adalah data sekunder yang berupa data panel (pooled data). Data panel ialah kombinasi antara data runtun waktu (time series) dan data silang tempat (cross section). Artinya, pada penelitian ini menggunakan gabungan data time series tahun 2010-2019 dengan data cross section 14 Kabupaten/Kota di Provinsi Kalimantan Barat. Kuncoro (2004) dengan menggunakan data panel akan meningkatkan kuantitas observasi, sehingga kekurangan kuantitas observasi dapat teratasi.

Metode pengambilan data yakni dengan melalui kegiatan penelitian kepustakaan (library research) yang bersumber dari Badan Pusat Statistik Kalimantan Barat. Data dihimpun dengan dan diinput ke dalam beberapa tabel atau daftar yang telah dipersiapkan sesuai variabel-variabel yang diperlukan dalam kerangka analisis. Serta data yang digunakan yakni produk Domestik Regional Bruto (PDRB) atas dasar harga Konstan seri 2010 dan PDRB Perkapita atas dasar harga Konstan seri 2010 di Provinsi Kalimantan Barat.

Variabel terikat diartikan sebagai variabel yang keberadaannya dipengaruhi oleh variabel bebas. Variabel dependen pada penelitian ini adalah ketimpangan pendapatan masyarakat antar wilayah di Provinsi Kalimantan Barat tahun 2011-2018.

Variabel tak terikat diartikan sebagai variabel yang keberadaannya dapat mempengaruhi variabel terikat. Dalam penelitian ini, yang menjadi variabel tak terikat adalah laju pertumbuhan ekonomi di Provinsi Kalimantan Barat tahun 2011-2018.

Terdapat dua variabel pada penelitian kali ini, yaitu laju pertumbuhan ekonomi dan ketimpangan pendapatan dengan penjelasan sebagai berikut:

\section{Laju Pertumbuhan Ekonomi}

Untuk variabel ini dinotasikan dengan simbol $\mathrm{X}$ dengan angka yang dinyatakan dalampersentase. Data laju pertumbuhan ekonomi ini berasal data pertumbuhan ekonomi di Provinsi Kalimantan Barat yang dipublikasikan oleh Badan Pusat Statistik (BPS) Provinsi Kalimantan Barat. Adapun rumus untuk mendapatkan laju pertumbuhan ekonomi adalah sebagai berikut:

$$
P E=\frac{P D B_{T}-P D B_{T-1}}{P D B_{T-1}} \times 100 \%
$$

$\mathrm{PE} \quad=$ Pertumbuhan Ekonomi

PDB $=$ Produk Domestik Bruto

$\mathrm{T}=$ Periode tertentu

$\mathrm{T}-1 \quad=$ Periode sebelumnya 


\section{Ketimpangan Pendapatan \\ Masyarakat antar Wilayah}

Ketimpangan pendapatan masyarakat antar wilayah pada penelitian ini merupakan perbedaan jumlah pendapatan tiap-tiap Kabupaten/Kota di Provinsi Kalimantan Barat. Variabel ini dinotasikan dengan simbol Y dengan satuan yang diterapkan guna menghitung ketimpangan pendapatan masyarakat antar wilayah yaitu Indeks Gini. Data yang dipakai berasal dari Gini Rasio yang dipublikasikan oleh Badan Pusat Statistik (BPS) Provinsi Kalimantan Barat tahun 2011-2018. Adapun rumus untuk mendapatkan ketimpangan pendapatan masyarakat antar wilayah dengan menggunakan gini rasio adalah sebagai berikut:

Rumus Gini Rasio:

$$
G R=1-\sum f_{i}\left[Y_{i}+Y_{i-1}\right]
$$

Keterangan:

Fi: Jumlah Persen (\%) penerima pendapatan kelas ke-i

Yi: Jumlah kumulatif (\%) pendapatan pada kelas ke-i

Terdapat dua jenis Teknik analisis pada penelitian ini, yaitu analisis statistic deskriptif dan regresi dengan metode data panel. Kegunaan dari jenis analisis statistic deskriptif adalah untuk menjelaskan kejadian atau fenomena dari serangkaian data sekunder sedangkan pada jenis analisis regresi digunakan untuk menjelaskan keterkaitan antar variabel satu dengan variabel yang lain dengan menggunakan metode (Generalized Least Squared) GLS yang dalam proses perhitungannya menggunakan program Eviews 10.0.

\section{a. Tipologi Klasen}

Menjawab tujuan pertama pada penelitian ini dilakukan dengan cara mengelompokkan Kabupaten/Kota yang berdasar pada dua alat ukur yakni laju pertumbuhan ekonomi dan ketimpangan pendapatan masyarakat antar wilayah, dalam penelitian ini menggunakan Klasen tipologi. Dengan memperoleh hasil perhitungan dari rata-rata pertumbuhan ekonomi Provinsi Kalimantan Barat dari tahun 2011-2018 sebagai sumbu vertikal dan rata-rata Gini Rasio Provinsi Kalimantan Barat sebagai sumbu horizontal.

Kemudian akan digolongkan kedalam 4 kuadran, yang artinya sebagai berikut: Kuadran I adalah untuk Kabupaten/Kota yang memiliki pertumbuhan ekonomi tinggi dan ketimpangan pendapatan masyarakat antar wilayah yang rendah dibandingkan dengan tingkat rata-rata Provinsi. Kuadran II adalah untuk Kabupaten/Kota dengan pertumbuhan ekonomi tinggi namun ketimpangan pendapatan masyaralat antar wilayah yang juga rendah dibandingkan dengan tingkat rata-rata Provinsi. Kuadran III adalah untuk Kabupaten/Kota dengan pertumbuhan ekonomi rendah namun ketimpangan pendapatan masyarakat antar wilayah yang juga rendah dibandingkan dengan tingkat rata-rata Provinsi. Kuadran IV adalah untuk Kabupaten/Kota dengan pertumbuhan ekonomi rendah dan ketimpangan pendapatan masyarakat antar wilayah yang tinggi dibandingkan dengan tingkat rata-rata Provinsi.

Tabel 4

Klasifikasi Kabupaten/Kota Menurut Pertumbuhan Ekonomi dan Ketimpangan Pendapatan antar Wilayah

\begin{tabular}{|c|c|c|}
\hline $\begin{array}{l}\text { PDRB/ } \\
\text { Kapita Laju } \\
\text { Pertumbuha } \\
\text { n }\end{array}$ & ydi > yni (+) & ydi $<$ yni $(-)$ \\
\hline$\underset{(+)}{\operatorname{Rdi}}>\mathbf{r n i}$ & $\begin{array}{l}\text { Kuadran I } \\
\text { Pertumbuhan } \\
\text { ekonomi tinggi } \\
\text { dan } \\
\text { ketimpangan } \\
\text { wilayah rendah }\end{array}$ & $\begin{array}{l}\text { Kuadran II } \\
\text { Pertumbuha } \\
\text { n ekonomi } \\
\text { tinggi dan } \\
\text { ketimpanga } \\
\text { n wilayah } \\
\text { tinggi }\end{array}$ \\
\hline$\underset{(-)}{\text { rdi }}<$ rni & $\begin{array}{l}\text { Kuadran III } \\
\quad \text { Pertu } \\
\text { mbuhan } \\
\text { ekonomi } \\
\text { rendah dan } \\
\text { ketimpanga }\end{array}$ & $\begin{array}{l}\text { Kuadran IV } \\
\text { Pertumbuha } \\
\mathrm{n} \text { ekonomi } \\
\text { rendah dan } \\
\text { ketimpanga } \\
\text { n wilayah } \\
\text { tinggi }\end{array}$ \\
\hline
\end{tabular}




\begin{tabular}{|l|l|l|}
\hline & $\begin{array}{l}\text { n wilayah } \\
\text { rendah }\end{array}$ & \\
\hline
\end{tabular}

Sumber: Sjafrizal 1997

Keterangan:

rdi : Laju Pertumbuhan Kabupaten/Kota ke-i

rni : Laju pertumbuhan total PDRB

Provinsi Kalimantan Barat

ydi : Pendapatan perkapita Kabupaten/Kota ke-i

yni: Pendapatan perkapita Provinsi

Kalimantan Barat

\section{b. Analisis Hipotesis Kuznets}

Kemudian untuk menjawab dari tujuan kedua yaitu mengenai Hipotesis Kuznets, maka dapat dibuktikan dengan membuat grafik antara ketimpangan pendapatan masyarakat antar wilayah yaitu dengan menggunakan data Gini Rasio dengan pertumbuhan ekonomi.

Gini Rasio merupakan suatu alat untuk mendeteksi ketimpangan pendapatan secara menyeluruh yang ditandai dengan nilai yang berkisar antara 1-0. Satu artinya adanya ketimpangan pendapatan yang sempurna. Nol artinya tidak adanya ketimpangan pendapatan yang sempurna atau dengan kata lain pemerataan sempurna.

Tabel: Patokan Nilai Koefisien Gini

\begin{tabular}{|l|l|}
\hline Nilai Koefisien & $\begin{array}{l}\text { Distribusi } \\
\text { Pendapatan }\end{array}$ \\
\hline$<0,4$ & $\begin{array}{l}\text { Tingkat } \\
\text { Ketimpangan } \\
\text { Rendah }\end{array}$ \\
\hline $0,4-0,5$ & $\begin{array}{l}\text { Tingkat } \\
\text { Ketimpangan Sedang }\end{array}$ \\
\hline$>0,5$ & $\begin{array}{l}\text { Tingkat } \\
\text { Ketimpangan Tinggi }\end{array}$ \\
\hline
\end{tabular}

Rumus Gini Rasio:

Keterangan:

$$
G R=1-\sum f_{i}\left[Y_{i}+Y_{i-1}\right]
$$

\footnotetext{
Fi: Jumlah Persen (\%) penerima pendapatan kelas ke-i

Yi: Jumlah kumulatif (\%) pendapatan pada kelas ke-i
}

Dengan ketentuan GR antara nol sampai dengan satu.

Bila GR: 0, pemerataan sempurna. Interpretasi dari nilai tersebut adalah tiap individu memiliki pendapatan yang sama antar individu satu dengan yang lainnya.

Bila GR: 1, ketimpangan pendapatan timpang sempurna. Interpretasi dari nilai tersebut adalah hanya beberapa kelompok saja yang menerima pendapatan yang tinggi dibandingkan dengan kelompok yang lain.

Kurva Kuznets akan mempresentasikan bahwa dalam jangka pendek hubungan antara pertumbuhan ekonomi dan ketimpangan pendapatan masyarakat antar wilayah bersifat positif yang ditandai dengan grafik yang meningkat. Kemudian jika sudah mencapai titik klimaks atau titik maksimumnya, maka dalam waktu yang cukup lama korelasi antara pertumbuhan ekonomi dan ketimpangan pendapatan masyarakat antar wilayah bersifat negatif yang ditandai dengan grafik yang menurun.

Menurut Kuznets pada tahap awal pembangunan ekonomi, ketimpangan pendapatan akan tinggi atau memburuk dan pada tahap berikutnya ketimpangan pendapatan akan menurun. Namun pada suatu waktu, ketimpangan akan meningkat dan demikian seterusnya. Sehingga terjadi peristiwa yang berulang kali (Todaro \& Smith, 2012). Jika digambarkan dalam bentuk kurva akan terbentuk kurva Uterbalik.

\section{c. Analisis Regresi Sederhana}

Model penelitian kali ini diadopsi dari penelitian yang dilakukan oleh Kurniasih (2013). Berikut model keterkaitan antara pertumbuhan ekonomi dan ketimpangan pendapatan masyarakat antar wilayah di Kabupaten/Kota Provinsi Kalimantan Barat:

$$
Y_{i t}=a_{0}+\beta_{1} x_{1 i t}+\epsilon_{i t}
$$

Keterangan:

$\mathrm{Y}=$ Ketimpangan pendapatan masyarakat antar wilayah ke-i, pada tahun $\mathrm{t}$

a_0 = Konstanta (yang menunjukkan besar nilai $\mathrm{y}$ bila nilai $\mathrm{x} \_1=0$ )

$\beta \_1=$ Koefisien Regresi (parameter regresi yang akan diestimasi) 
x_1 = Pertumbuhan Ekonomi ke-i, pada tahun $\mathrm{t}$

$\epsilon_{-}$it $=$Error Term (Residual)

i $=$ Wilayah 14 Kabupaten/Kota Provinsi Kalimantan Barat yang akan di observasi

$\mathrm{t}=$ periode observasi $(\mathrm{t}=2011-2018)$

\section{HASIL DAN PEMBAHASAN}

Berdasar pada ketiga tujuan penelitian dalam penulisan ini, maka terdapat tiga cara dalam menjawab tujuan dari penelitian yang dilakukan sebagai berikut, yaitu (1) tipologi pertumbuhan ekonomi dan ketimpangan pendapatan masyarakat antar daerah; (2) pembuktian Hipotesis Kuznets; (3) Pengaruh Ketimpangan pendapatan masyarakat antar daerah terhadap pertumbuhan ekonomi.

\subsection{Pertumbuhan Ekonomi dan Ketimpangan Pendapatan Masyarakat antar Wilayah}

Menjawab tujuan penelitian yang pertama dilakukan dengan cara mengklasifikasikan Kabupaten/Kota yang berdasar pada dua indicator, yakni pertumbuhan ekonomi dan ketimpangan pendapatan antar wilayah, dalam penelitian ini menggunakan Klasen Tipologi. Dengan menentukan rata-rata laju pertumbuhan ekonomi Provinsi Kalimantan Barat selama delapan tahun sebagai sumbu vertikal dan rata-rata ketimpangan pendapatan antar wilayah di Kalimantan Barat sebagai sumbu horizontal. Langkah yang dilakukan untuk mengklasifikasikan kedalam empat kuadran yang telah disediakan ini dengan cara membandingkan nilai laju pertumbuhan ekonomi kabupaten/kota terhadap provinsi di Kalimantan Barat. Sama hal nya untuk nilai ketimpangan pendapatan masyarakat antar wilayah, maka nilai yang dibandingkan adalah gini rasio kabupaten/Kota terhadap Provinsi di wilayah Kalimantan Barat.

Kemudian akan digolongkan kedalam 4 kuadran, yang artinya sebagai berikut: Kuadran I adalah untuk Kabupaten/Kota yang memiliki pertumbuhan ekonomi tinggi dan ketimpangan pendapatan masyarakat antar wilayah yang rendah dibandingkan dengan tingkat rata-rata Provinsi. Kuadran II adalah untuk Kabupaten/Kota dengan pertumbuhan ekonomi tinggi namun dengan ketimpangan pendapatan masyarakat antar wilayah yang juga tinggi dibanding dengan tingkat ratarata provinsi. Kuadran III adalah untuk Kabupaten/Kota dengan pertumbuhan ekonomi rendah namun ketimpangan pendapatan masyarakat antar wilayah yang juga rendah dibandingkan dengan tingkat rata-rata Provinsi. Kuadran IV adalah untuk Kabupaten/Kota dengan pertumbuhan ekonomi rendah dan ketimpangan pendapatan masyarakat antar wilayah yang tinggi dibandingkan dengan tingkat rata-rata Provinsi.

\begin{tabular}{|c|c|c|}
\hline $\begin{array}{l}\text { PDRB/ } \\
\text { Kapita } \\
\text { Laju } \\
\text { Pertumbuhan }\end{array}$ & ydi > yni $(+)$ & ydi < yni (-) \\
\hline Rdi > rni (+) & $\begin{array}{l}\text { Kuadran I } \\
\text { Pertumbuhan } \\
\text { ekonomi } \\
\text { tinggi dan } \\
\text { ketimpangan } \\
\text { pendapatan } \\
\text { masyarakat } \\
\text { antar wilayah } \\
\text { rendah: } \\
\text { Kabupaten } \\
\text { Sambas }\end{array}$ & $\begin{array}{l}\text { Kuadran II } \\
\text { Pertumbuhan } \\
\text { ekonomi tinggi } \\
\text { dan ketimpangan } \\
\text { pendapatan } \\
\text { masyarakat antar } \\
\text { wilayah tinggi: } \\
\text { Kabupaten } \\
\text { Ketapang, } \\
\text { Kabupaten } \\
\text { Sekadau, } \\
\text { Kabupaten Kubu } \\
\text { Raya, } \\
\text { Pontianak, Kota } \\
\text { Singkawang }\end{array}$ \\
\hline rdi $<\operatorname{rni} \quad(-)$ & $\begin{array}{l}\text { Kuadran III } \\
\text { Pertumbuhan } \\
\text { ekonomi } \\
\text { rendah dan } \\
\text { ketimpangan } \\
\text { pendapatan } \\
\text { masyarakat } \\
\text { antar wilayah } \\
\text { rendah: }\end{array}$ & $\begin{array}{l}\text { Kuadran IV } \\
\text { Pertumbuhan } \\
\text { ekonomi rendah } \\
\text { dan ketimpangan } \\
\text { pendapatan } \\
\text { masyarakat antar } \\
\text { wilayah tinggi: } \\
\text { Kab.Bengkayang, } \\
\text { Kab.Landak, Kab. } \\
\text { Mempawah, Kab. } \\
\text { Sanggau, Kab. } \\
\text { Sintang, Kab. } \\
\text { Kapuas Hulu, Kab. } \\
\text { Melawi, Kab. } \\
\text { Kayong Utara. }\end{array}$ \\
\hline
\end{tabular}


Tabel 5

Klasifikasi Kabupaten/Kota Menurut Pertumbuhan Ekonomi dan Ketimpangan Pendapatan Masyarakat antar Wilayah

Sumber: Data diolah, 2021

Keterangan:

rdi : rata-rata laju pertumbuhan ekonomi Kabupaten/Kota ke-i

rni : laju pertumbuhan ekonomi total PDRB Provinsi Kalimantan Barat ke-i

ydi : rata-rata ketimpangan pendapatan masyarakat antar wilayah Kabupaten/Kota ke-i

yni : ketimpangan pendapatan masyarakat antar wilayah Provinsi Kalimantan Barat ke-i

\section{a. Hasil Temuan Analisis menurut}

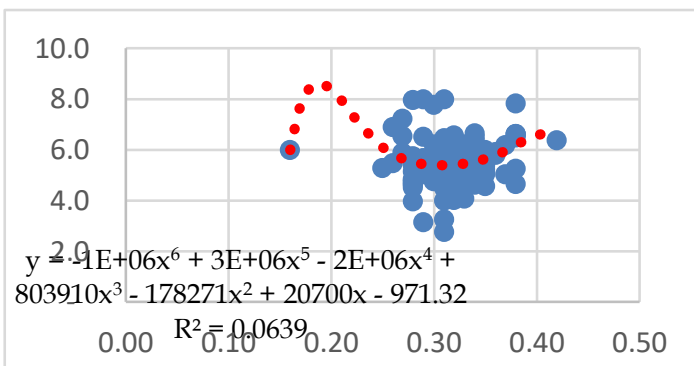

Hipotesis Kuznets

Sumber: Data diolah, 2021

Gambar 3

Kurva Hubungan antara Pertumbuhan Ekonomi dengan Gini Rasio di Provinsi Kalimantan Barat Tahun 2011-2018

\section{b. Pengaruh Ketimpangan Pendapatan Masyarakat antar Wilayah terhadap Pertumbuhan Ekonomi.}

Berdasarkan hasil olah data dengan menggunakan aplikasi Eviews 10, berikut perolehan pemilihan teknik estimasi regresi data panel (pooled data):

\section{a. Pemilihan Model yang Tepat}

Pemilihan model yang tepat digunakan untuk memilih model yang paling tepat antara Common Effect Model (CEM) atau Fixed Effect Model (FEM) atau Random Effect Model (REM). Hal pertama yang dilakukan pada penelitian kali ini ialah uji Chow. Uji Chow dilakukan untuk membuat keputusan apakah model Common Effect lebih baik digunakan daripada model Fixed Effect. Kedua dilakukan Uji Hausman dilakukan untuk membuat keputusan apakah model Common Effect lebih baik digunakan dari pada model Fixed Effect. Ketiga, akan dilakukan uji Breusch Pagan - Legrange Multiplier, yang digunakan untuk uji signifikansi Random Effect dilakukan untuk menentukan apakah model Random Effect lebih baik digunakan daripada model Common Effect.

\section{Uji Chow Test}

Tabel 6. Hasil Uji Chow Test

\begin{tabular}{|l|l|l|l|}
\hline $\begin{array}{l}\text { Effect } \\
\text { Test }\end{array}$ & Statistic & df. & Prob. \\
\hline $\begin{array}{l}\text { Cross- } \\
\text { section } \\
\text { F }\end{array}$ & 3.105195 & $(13,97)$ & 0.0007 \\
\hline
\end{tabular}

Sumber: Data diolah, 2021

Berdasarkan hasil uji chow test di atas, maka didapati nilai Probabilitasnya sebesar 0,0007. Hasil ini menunjukkan bahwa nilai Probabilitas lebih kecil daripada $\alpha$, yakni $0,0007<0,05$. Oleh karena ini Ha diterima, sehingga model yang tepat dari hasil uji chow test adalah model fixed effect.

\section{Uji Husman Test}

Tabel 7. Hasil Uji Hausman Test

\begin{tabular}{|c|c|c|c|}
\hline $\begin{array}{c}\text { Test } \\
\text { Summary }\end{array}$ & $\begin{array}{c}\text { Chi-Sq. } \\
\text { Statistic }\end{array}$ & $\begin{array}{c}\text { Chi-Sq. } \\
\text { df. }\end{array}$ & Prob. \\
\hline $\begin{array}{c}\text { Cross- } \\
\text { section } \\
\text { random }\end{array}$ & 4.510781 & 1 & 0.0337 \\
\hline
\end{tabular}

Sumber: Data diolah, 2021

Berdasarkan hasil uji Hausman test di atas, maka didapati hasil probabilitasnya sebesar 0,0337. Hasil ini menunjukkan bahwa nilai probabilitasnya lebih kecil daripada $\alpha$, yakni $0,0337<0,05$. Oleh karena ini Ha diterima, sehingga model yang tepat dari hasil uji chow test adalah model fixed effect.

\section{b. Hasil Uji Statistik Analisis Regresi}




\section{Uji Koefisien Determinasi $\left(R^{2}\right)$ Tabel 8}

Estimasi Model Persamaan Regresi Data Panel Pendekatan Fixed Model (FEM)

\begin{tabular}{|l|l|l|l|l|}
\hline \multicolumn{5}{|c|}{$\begin{array}{l}\text { Variabel Dependent } \\
\text { Gini Rasio (GR) }\end{array}$} \\
\hline $\begin{array}{l}\text { Variable } \\
\text { Independ } \\
\text { ent }\end{array}$ & $\begin{array}{l}\text { Koefisi } \\
\text { en }\end{array}$ & $\begin{array}{l}\text { Std. } \\
\text { Error }\end{array}$ & $\begin{array}{l}\text { t- } \\
\text { Statisti } \\
\text { c }\end{array}$ & Prob \\
\hline $\mathrm{C}$ & $\begin{array}{l}0.3147 \\
78\end{array}$ & $\begin{array}{l}0.0234 \\
99\end{array}$ & $\begin{array}{l}13.395 \\
61\end{array}$ & $\begin{array}{l}0.00 \\
00\end{array}$ \\
\hline PE? & 0.0002 & 0.0042 & 0.0626 & 0.95 \\
& 66 & 41 & 51 & 02 \\
\hline$R^{2}$ & \multicolumn{4}{|c|}{0.305165} \\
\hline $\begin{array}{l}\text { Prob (F- } \\
\text { statistik) }\end{array}$ & \multicolumn{4}{|c|}{0.000640} \\
\hline
\end{tabular}

Sumber: Data diolah, 2021

Berdasarkan dari uji chow test dan uji hausman test, maka dapat disimpulkan bahwa pemilihan model yang paling tepat dalam penelitian kali ini yakni dengan menggunakan fixed effect model (FEM).

\section{Uji Signifikan Parameter Individual (Uji t Statistik)}

Berdasarkan table 3, dapat dibuat persamaan regresi data panel sebagai berikut:

$G R_{i t}=0,314778+0,000266$ $\left.P E_{i t} \ldots \ldots \ldots . . .1\right)$

Berdasarkan hasil regresi data panel didapati hasil koefisien determinasi $\left(\mathrm{R}^{\wedge} 2\right)$ sebesar 0.305165 . artinya persentase perubahan dari variable gini rasio kabupaten/kota Provinsi Kalimantan Barat dapat dijelaskan oleh variabel pertumbuhan ekonomi sebesar $30,52 \%$ sedangkan sisanya sebesar $69,48 \%$ dijelaskan oleh faktor-faktor yang tidak terdapat pada penelitian kali ini.

\section{PEMBAHASAN}

Berdasarkan analisis dengan menggunakan tipologi klasen di atas yang di mana Provinsi Kalimantan Barat yang terdiri dari 14 Kabupaten/Kota dibagi menjadi 4 kuadran berdasar pada laju pertumbuhan ekonomi dan ketimpangan pendapatan masyarakat antar wilayah, maka hasil klasifikasi per Kabupaten/Kota dari tahun 2011-2018 adalah sebagai berikut:

\section{a. Kuadran I:}

Kabupaten/Kota yang tergolong cepat maju dan cepat tumbuh yang memiliki kriteria rata-rata laju pertumbuhan ekonomi Kabupaten/kota yang nilainya lebih besar daripada Provinsi Kalimantan Barat sebesar $5,67 \%$ dan rata-rata tingkat ketimpangan pendapatan masyarakat antar wilayah yang (ditandai dengan angka gini rasio) rendah daripada Provinsi Kalimantan Barat sebesar -2,07. Kabupaten/Kota yang dimaksud adalah hanya Kabupaten Sambas.

Untuk Kuadran I yaitu kuadran yang memiliki karakteristik pertumbuhan ekonomi yang tinggi dan ketimpangan pendapatan masyarakat antar wilayah yang rendah pula, saya akan menganalisis lebih dalam pada Kabupaten Sambas. Jika kita melihat secara PDRB sektoralnya, untuk 17 sektor di Kabupaten Sambas ini memiliki data yang menarik, di mana untuk setiap sektornya itu nyaris memiliki sumbangsih yang sama atau setara dari sektor satu ke sector yang lainnya. Bahkan untuk sector tertinggi itu di sector jasa lainnya yang sebesar $7,70 \%$ dan disusul oleh jasa Kesehatan dan kegiatan sosial yaitu sebesar $6,81 \%$ dan untuk sektor terbesar ketiga yaitu pengadaan air, pengelolaan sampah dan daur ulang itu sebesar $6,62 \%$. Bahkan jika digabungkan ketiga sektor terbesar ini hanya mencapai nilai kurang dari $20 \%$, yang dimana membuktikan bahwa pemerataan struktur sektoral pertumbuhan ekonomi di Kabupaten Sambas, yang di mana tidak ada setiap sektor yang memiliki sumbansih sebesar 10\%. Yang berarti untuk setiap sector tersebut dapat dijalankan oleh berbagai lapisan masyarakat dan sumbangsih nya nyaris sama, jadi tidak ada yang lebih besar dari 10\% bahkan 20\%, tidak seperti di daerah Kabupaten Sintang dan juga daerah Kota Pontianak yang memiliki ketimpangan di sektor-sektor tertentu, sehingga mengakibatkan untuk nilai dari ketimpangan pendapatan masyarakat antar wilayah pun rendah pula. 
b. Kuadran II:

Kabupaten/Kota yang tergolong berkembang cepat (growing region), yakni Kabupaten/Kota yang dicirikan dengan ratarata laju pertumbuhan ekonomi tinggi dan ketimpangan pendapatan masyarakat antar wilayah juga tinggi dibandingkan dengan rata-rata Provinsi Kalimantan Barat. Ratarata laju pertumbuhan ekonomi Provinsi $5,67 \%$ dan tingkat ketimpangan pendapatan masyarakat antar wilayah di Provinsi sebesar -2,07. Kabupaten/Kota yang dimaksud adalah Kabupaten Ketapang, Kabupaten Sekadau, Kabupaten Kubu Raya, Kota Pontianak, dan Kota Singkawang. Artinya pada Kabupaten/Kota yang tergolong dalam kuadran II ini belum mampu memberikan dampak yang positif bagi daerah di sekitarnya.

Pada kuadran II ini saya akan mencoba untuk menganalisis secara lebih mendalam mengenai daerah Kota Pontianak. Sebelumnya Kuadran II ini memiliki karakteristik yaitu memiliki pertumbuhan ekonomi yang tinggi, namun memiliki tingkat ketimpangan pendapatan masyarakat antar wilayah yang tinggi pula. Untuk daerah Pontianak, jika dilihat lebih mendalam mengenai proporsi dari PDRB sektoral nya, didominasi oleh 3 sektor terbesar dari 17 sektornya. Yaitu, sektor perdagangan besar yang memiliki proporsi sebesar $17,88 \%$. Dan terbesar kedua disusul oleh sektor Industri Pengolahan, yaitu sebesar $17,41 \%$. Dan yang terakhir urutan ketiga pada sektor konsumsi sebesar $16,04 \%$. Jika kita menggabungkan tiga sector besar ini, nilainya sebesar 51, 33\% yang merupakan setengah dari total PDRB 17 sektoral tersebut. Hal ini menunjukkan bahwa daerah Pontianak memiliki basis perdagangan dan distribusi barang, sehingga komoditas yang dihasilkan juga memiliki nilai tambah (value edit) yang menimbulkan atau menunjukkan level harga produk yang cenderung konsisten dan stabil di pasaran. Mengapa kota Pontianak memiliki tingkat ketimpangan pendapatan yang tinggi pula? Hal ini dikarenakan jika dilihat dari tiga sektor pendorong utama ini dimiliki oleh pihak swasta, yang dimana dengan adanya sektor tersebut akan meningkatkan aglomerasi pertumbuhan ekonomi. Dan daerah yang lainnya merupakan daerah sub urban, yang di mana sektor yang lainnya hanya bersifat penunjang saja. Hal ini lah yang menjadikan Kota Pontianak memiliki tingkat ketimpangan pendapatan masyarakat antar wilayah yang tinggi.

\section{c. Kuadran III:}

Kabupaten/Kota yang tergolong maju tetapi tertekan (retared region), yakni Kabupaten/kota yang dicirikan dengan ratarata laju pertumbuhan ekonomi rendah dan ketimpangan pendapatan masyarakat antar wilayah rendah dibandingkan dengan ratarata Provinsi Kalimantan Barat. Rata-rata laju pertumbuhan ekonomi Provinsi 5,67\% dan tingkat ketimpangan pendapatan masyarakat antar wilayah di Provinsi sebesar -2,07. Dalam penelitian kali ini, tidak didapati Kabupaten/Kota Provinsi Kalimantan Barat yang tergolong kedalam Kuadran III.

\section{d. Kuadran IV:}

Kabupaten/Kota yang tergolong relatif tertinggal (relative backward region) yakni Kabupaten/kota yang dicirikan dengan ratarata laju pertumbuhan ekonomi rendah dan ketimpangan pendapatan masyarakat antar wilayah tinggi dibandingkan dengan ratarata Provinsi Kalimantan Barat. Rata-rata laju pertumbuhan ekonomi Provinsi 5,67\% dan tingkat ketimpangan pendapatan masyarakat antar wilayah di Provinsi sebesar -2,07. Kabupaten/Kota yang dimaksud adalah Kabupaten Bengkayang, Kabupaten Landak, Kab. Mempawah, Kab. Sanggau, Kab. Sintang, Kab. Kapuas Hulu, Kab. Melawi, dan Kab. Kayong Utara.

Sebelumnya saya akan menjelaskan kembali mengenai karakteristik dari kuadran IV ini, yaitu memiliki pertumbuhan ekonomi yang rendah dan juga ketimpangan pendapatan masyarakat yang rendah pula. Sebagai contoh pada Kabupaten Sintang, jika dilihat dari proporsi pertumbuhan ekonominya, dari PDRB nya itu sendiri masih ditunjang oleh sektor yang sederhana yaitu sektor pertanian dan perikanan, yaitu sekitar 21,26\% dari 
BPS 2019. Artinya seperempat dari total PDRB Kabupaten Sintang masih ditunjang oleh sektor yang memiliki komuditas dari sifat dan level nya itu masih mudah berfluktuatif nilainya. Hal ini dikarenakan kurangnya nilai tambah (value edit), bahkan tidak memiliki nilai tambah sama sekali yang di mana masih tergolong pada low material atau masih bersifat barang mentah, sehingga untuk tingkat fluktuatif di pasaran itu cenderung naik dan bahkan turun secara tidak stabil. Begitu juga dengan Pontianak dengan memiliki sektor pertanian, kehutanan, dan perikanan, tentunya akan menciptakan sektoral-sektoral di berbagai daerah, sehingga adanya pusat pertumbuhan ekonomi penduduk itu hanya ada di daerahdaerah tertentu dan hanya dimiliki oleh segelintir orang saja. Karena untuk memiliki lahan pertanian atau perikanan maka diperlukannya lahan yang luas serta memiliki dana pengelolaan yang juga cukup besar, sehingga hanya dimiliki oleh segelintir golongan masyarakat yang memiliki dana tersebut dan mempekerjakan masyarakat yang besar pula. Sehingga untuk membuat hal tersebut dibutuhkan modal yang besar pula.

Kuznets (1955) menemukan bahwa terdapat hubungan antara pertumbuhan ekonomi dan ketimpangan pembangunan. Ia menyatakan bahwa hubungan keduanya dapat dinyatakan seperti gambar kurva U-terbalik. Kurva tersebut mempresentasikan bahwa dalam jangka pendek hubungan antara pertumbuhan ekonomi dan ketimpangan pembangunan bersifat positif yang ditandai dengan grafik yang meningkat. Kemudian jika sudah mencapai titik klimaks atau titik maksimumnya, maka dalam jangka panjang hubungan antara pertumbuhan ekonomi dan ketimpangan pembangunan bersifat negatif yang ditandai dengan grafik yang menurun. Berdasarkan kurva hubungan antara pertumbuhan ekonomi dengan gini rasio di Provinsi Kalimantan Barat tahun 2011-2018, menggambarkan bahwa pada tahap awal hingga akhir pertumbuhan ekonomi tingkat ketimpangan pendapatan masyarakat antar wilayah di Provinsi Kalimantan Barat yang ditandai dengan gini rasio berfluktuatif di setiap tahunnya.

Dari tahun 2011 sampai dengan 2014 koefisien gini rasio di Kalimantan Barat mengalami kenaikan di setiap tahunnya. Pada tahun 2014 angka gini rasionya sangat tinggi, yakni 0,397 . Kemudian pada tahun 2015 angka gini rasio di kalimantan barat mengalami penurunan yang sangat drastis sehingga pertumbuhan gini rasionya menjadi $16.27 \%$ atau mengalami penurunan sebesar 0,065 poin. Pada tahun 2016 naik kembali sebesar 0,004 poin atau mengalami kenaikan pertumbuhan gini rasio sebesar $1,20 \%$. Kemudian turun kembali pada tahun 2017 sebesar 0,008 poin atau mengalami penurunan pertumbuhan gini rasio sebesar 2,38\%. Kemudian naik kembali pada tahun 2018 sebesar 0,004 poin atau mengalami kenaikan pertumbuhan gini rasio sebesar $1.22 \%$.

Berdasarkan Gambar 3 dengan menggunakan model terbaik yakni polynomial sampai pada pangkat 6 menghasilkan bentuk hubungan yang berfluktuatif selama 8 tahun periode pengamatan. Kurva tersebut mempresentasikan bahwa dalam jangka pendek hubungan antara pertumbuhan ekonomi dan ketimpangan pendapatan masyarakat antar wilayah bersifat positif yang ditandai dengan grafik yang meningkat. Kemudian sudah mencapai titik klimaks atau titik maksimumnya pada tahun 2015, maka dalam jangka panjang hubungan antara pertumbuhan ekonomi dan ketimpangan pendapatan masyarakat antar wilayah bersifat negatif yang ditandai dengan grafik yang menurun. Sehingga terbentuklah kurva U-Terbalik. Maknanya dalam penelitian kali ini, berlakunya teori hipotesis Kuznets di Provinsi Kalimantan Barat selama periode pengamatan tahun 2011-2018.

Hal ini dikarenakan secara khusus, pada lampiran 10 mengenai Kurva Hubungan antara Pertumbuhan Ekonomi dengan Gini Rasio di Provinsi Kalimantan Barat Tahun 2011 didapati bentuk hubungan antara pertumbuhan ekonomi dan gini rasio adalah 
negatif (-11.656 x) dengan besaran hubungan keduanya adalah 0,157 . Artinya semakin tinggi pertumbuhan ekonomi maka ketimpangan pendapatan masyarakat antar wilayah di Kalimantan Barat semakin rendah.

Lampiran 11 mengenai Kurva Hubungan antara Pertumbuhan Ekonomi dengan Gini Rasio di Provinsi Kalimantan Barat Tahun 2012 didapati bentuk hubungan antara pertumbuhan ekonomi dan gini rasio adalah negatif $(-4.4703 \mathrm{x})$ dengan besaran hubungan keduanya adalah 0,0179. Artinya semakin tinggi pertumbuhan ekonomi maka ketimpangan pendapatan masyarakat antar wilayah di Kalimantan Barat semakin rendah.

Lampiran 12 mengenai Kurva Hubungan antara Pertumbuhan Ekonomi dengan Gini Rasio di Provinsi Kalimantan Barat Tahun 2013 didapati bentuk hubungan antara pertumbuhan ekonomi dan gini rasio adalah positif (16.362 x) dengan besaran hubungan keduanya adalah 0,4653 . Artinya semakin tinggi pertumbuhan ekonomi maka ketimpangan pendapatan masyarakat antar wilayah di Kalimantan Barat semakin tinggi. Lampiran 13 mengenai Kurva Hubungan antara Pertumbuhan Ekonomi dengan Gini Rasio di Provinsi Kalimantan Barat Tahun 2014 didapati bentuk hubungan antara pertumbuhan ekonomi dan gini rasio adalah positif (15.335 x) dengan besaran hubungan keduanya adalah 0,2281. Artinya semakin tinggi pertumbuhan ekonomi maka ketimpangan pendapatan masyarakat antar wilayah di Kalimantan Barat semakin tinggi. Lampiran 14 mengenai Kurva Hubungan antara Pertumbuhan Ekonomi dengan Gini Rasio di Provinsi Kalimantan Barat Tahun 2015 didapati bentuk hubungan antara pertumbuhan ekonomi dan gini rasio adalah positif (19.245 x) dengan besaran hubungan keduanya adalah 0,2826. Artinya semakin tinggi pertumbuhan ekonomi maka ketimpangan pendapatan masyarakat antar wilayah di Kalimantan Barat semakin tinggi. Lampiran 15 mengenai Kurva Hubungan antara Pertumbuhan Ekonomi dengan Gini Rasio di Provinsi Kalimantan Barat Tahun
2016 didapati bentuk hubungan antara pertumbuhan ekonomi dan gini rasio adalah negatif $(-3.379 \mathrm{x})$ dengan besaran hubungan keduanya adalah 0,0512 . Artinya semakin tinggi pertumbuhan ekonomi maka ketimpangan pendapatan masyarakat antar wilayah di Kalimantan Barat semakin rendah.

Lampiran 16 mengenai Kurva Hubungan antara Pertumbuhan Ekonomi dengan Gini Rasio di Provinsi Kalimantan Barat Tahun 2017 didapati bentuk hubungan antara pertumbuhan ekonomi dan gini rasio adalah negatif $(-0.4138 \quad \mathrm{x})$ dengan besaran hubungan keduanya adalah 0,0002. Artinya semakin tinggi pertumbuhan ekonomi maka ketimpangan pendapatan masyarakat antar wilayah di Kalimantan Barat semakin rendah.

Lampiran 17 mengenai Kurva Hubungan antara Pertumbuhan Ekonomi dengan Gini Rasio di Provinsi Kalimantan Barat Tahun 2018 didapati bentuk hubungan antara pertumbuhan ekonomi dan gini rasio adalah negatif $(-7.1405 \mathrm{x})$ dengan besaran hubungan keduanya adalah 0,0653 . Artinya semakin tinggi pertumbuhan ekonomi maka ketimpangan pendapatan masyarakat antar wilayah di Kalimantan Barat semakin rendah.

Sesuai dengan hipotesis Kuznets, pada tahap awal pertumbuhan ekonomi maka akan berpengaruh pada buruknya distribusi pendapatan, pada tahap berikutnya distribusi pendapatan akan membaik seiring berjalannya waktu, dan pada jangka waktu yang lebih panjang akan terjadi ketimpangan distribusi pendapatan lagi seperti pada tahap awal pertumbuhan ekonomi dan akan kembali membaik lagi seiring berjalannya waktu (Putri, Amar, \& Aimon, 2015). Pada hasil perhitungan di atas menunjukkan bahwa variable pertumbuhan ekonomi berpengaruh positif terhadap variabel ketimpangan pendapatan masyarakat antar wilayah. Artinya bahwa variabel pertumbuhan ekonomi berbanding lurus dengan peningkatan output akibat dari peningkatan jumlah produksi. Selanjutnya, akibat dari bertambahnya jumlah output 
produksi ini, akan berbanding lurus juga terhadap peningkatan pendapatan perkapita yang pada akhirnya ketimpangan pendapatan antar wilayah mengecil (Kurniasih, 2013).

Sesuai dengan hasil estimasi persamaan data panel dengan pendekatan FEM, diperoleh hasil analisis bahwa variabel pertumbuhan ekonomi menunjukkan arah hubungan yang positif dan secara statistic tidak signifikan terhadap ketimpangan pendapatan masyarakat antar wilayah, pada tingkat signifikansi $\alpha=0,05$ persen. Hal ini ditunjukkan oleh nilai probabilitas sebesar $0.9502>0.05$ persen, artinya setiap kenaikan sebesar $1 \%$ pertumbuhan ekonomi akan mengakibatkan peningkatan ketimpangan pendapatan masyarakat antar wilayah (Indeks Gini) Kabupaten/Kota di Provinsi Kalimantan Barat sebesar 0.000266 dengan asumsi ceteris paribus.

Berdasarkan hasil analisis di atas, menunjukkan bahwa terdapat arah hubungan yang positif dan secara statistik tidak signifikan antara variabel pertumbuhan ekonomi dan ketimpangan pendapatan masyarakat antar wilayah di Provinsi Kalimantan Barat ini dapat disebabkan oleh pertumbuhahan ekonomi yang berfluktuatif serta belum terjadinya pemerataan distribusi pendapatan.

Berdasarkan hasil klasifikasi tipologi klasen, dapat pula disampaikan bahwa pertumbuhan ekonomi yang tinggi pada Kabupaten/Kota di Provinsi Kalimantan Barat tidak menutup kemungkinan bahwa terjadinya pemerataan distribusi pendapatan atau dengan kata lain bahwa ketimpangan pendapatan masyarakat antar wilayah masih terjadi walau tergolong pada ketimpangan yang sedang. Dalam kasus ini dapat pula dikatakan bahwa pertumbuhan ekonomi bukanlah merupakan syarat utama dalam mencapai tingkat ketimpangan yang rendah di suatu wilayah. Terdapat kondisi yang berbeda-beda yang dihadapi oleh masing-masing daerah dalam hal pencapaian pertumbuhan ekonominya. Seperti yang telah dijelaskan oleh Sjafrizal (2017), bahwa disparitas atau ketimpangan pendapatan ini berasal dari perbedaan faktor sumber daya alam dan terdapatnya perbedaan kondisi demografi yang dimiliki oleh masing-masing daerah. Karena adanya perbedaan inilah yang menyebabkan berbeda pula kemampuan yang dimiliki oleh tiap-tiap daerah dalam hal peningkatan perekonomian serta dalam hal mendongkrak pembangunan di wilayahnya. Oleh sebab itu, terdapatnya golongan wilayah yang relatif maju (developed region) dan wilayah relative terbelakang (underdeveloped region). Hasil penelitian ini sejalan pula dengan studi yang dilakukan oleh Islami (2018), Mukhlis, Hidayah dan Sariyani (2018), dan Trimurti, et. al (2018). Namun berbanding terbalik dengan hasil studi yang dilakukan oleh Kurniasih (2013), Yuliani (2015), Amri (2017), dan Alin, Heribertga, \& Umiyati (2019).

\section{KESIMPULAN}

Berdasarkan hasil pembahasan di bagian 4 maka dapat ditarik beberapa kesimpulan sebagai berikut:

1. Berdasarkan hasil klasifikasi tipologi klasen, bahwa ketimpangan pendapatan masyarakat antar wilayah masih terjadi walau tergolong pada ketimpangan yang sedang. Dalam kasus ini dapat pula dikatakan bahwa pertumbuhan ekonomi bukanlah merupakan syarat utama dalam mencapai tingkat ketimpangan yang rendah di suatu wilayah. Terdapat kondisi yang berbeda-beda yang dihadapi oleh masing-masing daerah dalam hal pencapaian pertumbuhan ekonominya.

2. Secara keseluruhan, data menunjukkan bahwa tingkat ketimpangan pendapatan masyarakat antar wilayah di provinsi Kalimantan Barat yang dinyatakan dalam angka gini rasio adalah berfluktuatif selama periode penelitian 2011-2018. Bedasarkan pada Gambar 3 kurva yang terbentuk menghasilkan seperti bentuk kurva U-Terbalik selama periode pegamatan dari tahun 2011-2018. Maknanya dalam penelitian kali ini, berlakunya teori hipotesis Kuznets di Provinsi Kalimantan Barat selama periode pengamatan tahun 2011-2018. 
3. Berdasarkan hasil analisis di atas, menunjukkan bahwa terdapat arah hubungan yang positif dan secara statistik tidak signifikan antara variabel pertumbuhan ekonomi dan ketimpangan pendapatan masyarakat antar wilayah di Provinsi Kalimantan Barat ini dapat disebabkan oleh pertumbuhahan ekonomi yang berfluktuatif serta belum terjadinya pemerataan distribusi pendapatan.

\section{DAFTAR PUSTAKA}

Adrei, A., \& Craciun, L. (2015). Inequality and Economic Growth: Theoretical and Operational Approach. Theorical \& Applied Economics, 22(1).

Amri, K. (2017). Analisis Pertumbuhan Ekonomi dan Ketimpangan Pendapatan: Panel Data 8 Provinsi di Sumatera. Jurnal Ekonomi dan Manajemen Teknologi, 1(1), 1-11.

Badan Pusat Statistik. (2020). [Seri 2010] Produk Domestik Regional Bruto berdasarkan Harga Konstan Provinsi Kalimantan Barat 2010-2019. Kalimantan Barat: BPS.

Badan Pusat Statistik. (2020). [Seri 2010] Produk Domestik Regional Bruto berdasarkan Harga Konstan Provinsi Kalimantan Timur 2010-2019. Kalimantan Timur: BPS.

Badan Pusat Statistik. (2020). [Seri 2010] Produk Domestik Regional Bruto berdasarkan Harga Konstan Provinsi Kalimantan Selatan 2010-2019. Kalimantan Selatan: BPS.

Badan Pusat Statistik. (2020). [Seri 2010] Produk Domestik Regional Bruto berdasarkan Harga Konstan Provinsi Kalimantan Tengah 2010-2019. Kalimantan Tengah: BPS.

Badan Pusat Statistik. (2020). [Seri 2010] Produk Domestik Regional Bruto perkapita berdasarkan Harga Konstan
Provinsi Kalimantan Timur 20102019. Kalimantan Timur: BPS.

Badan Pusat Statistik. (2020). [Seri 2010] Produk Domestik Regional Bruto perkapita berdasarkan Harga Konstan menurut Kabupaten/Kota Provinsi Kalimantan Barat 2014-2018. Kalimantan Barat: BPS.

Badan Pusat Statistik. (2020). Gini Rasio Provinsi Kalimantan Barat 20112020. Kalimantan Barat: BPS.

Creswell, J. W. (2016). Research Design Pendekatan Metode Kualitatif, Kuantitatif dan Campuran (Edisi ke6). Yogyakarta: Pustaka Pelajar.

Djarwanto, P.S. \& Subagyo, P. (2005). Statistik Induktif. Edisi Kelima. Yogyakarta: BPFE.

Islami, S. F. (2018). Faktor-Faktor Mempengaruhi Ketimpangan Wilayah di Provinsi Jawa Timur, Indonesia. Media Ekonomi dan Manajemen, 33 (1), 29-39.

Kuncoro, M. (2004). Otonomi dan Pembangunan Daerah: Reformasi. Perencanaan, Strategi dan Peluang. Jakarta: Erlangga.

Kurniasih, E. P. (2013). Ketimpangan Wilayah di Provinsi Kalimantan Barat Suatu Kajian Terhadap Hipotesis Kuznets. PJ-Eksos, 9 (1), $36-48$.

Kuznets, S. (1955). Economic growth and income inequality. The American Economic Review, 45 (1), 1-28.

Mukhlis, I., Hidayah, I., \& Sariyani. (2018). Economic Agglomeration, Economic Growth and Income Inequality in Regional Economies. Economic Journal of Emerging Markets, 10 (2), 205-212.

Nachrowi, N. D. \& Hardius, U. (2006). Pendekatan Populer dan Praktis Ekonometrika untuk Analisis 
Ekonomi dan Keuangan. Jakarta: LPFE Universitas Indonesia.

Putri, Y. E., Amar., Syamsul., \& Aimon. H. (2015). Analisis Faktor-Faktor yang Mempengaruhi Pertumbuhan Ekonomi dan Ketimpangan Pendapatan di Indonesia. Jurnal Kajian Ekonomi, 3 (6).

Raswita, N. P. M. E., \& Made, S. U. (2013). Analisis Pertumbuhan Ekonomi dan Ketimpangan Pendapatan Antar Kecamatan di Kabupaten Gianyar 2013. E-Jurnal EP Unus, 2 (3), 119128.

Sjafrizal. (1997). Pertumbuhan Ekonomi dan Ketimpangan Regional Wilayah Indonesia Bagian Barat. Prisma. Nomor 3 tahun XXVI. 34-52. Jakarta: Pustaka LP3ES Indonesia.

Sjafrizal. (2012). Ekonomi Wilayah dan Perkotaan. Jakarta: Raja Grafindo Persada.

Tambunan, T. (2004). Perekonomian Indonesia: Teori dan Temuan Empiris. Jakarta: Ghalia Indonesia.
Tambunan, T. (2014). In Perekonomian Indoneisa: Teori dan Temuan Empiris. Jakarta: Ghalia Indonesia.

Todaro, M. P. \& Smith, S.C. (2012). Economic Development (11th ed). New York: Pearson.

Trimurti. C. P., Komalawati, \& Mertayasa. I. G. A. (2018). Determinan Ketimpangan Pendapatan di Provinsi Bali. Prosiding Sintesa. ISBN: 978602-53420-0-4.

Widarjono, A. (2007). Ekonometrika: Teori dan Aplikasi untuk Ekonomi dan Bisnis, Edisi Kedua. Yogyakarta: Ekonisia FE Universitas Islam Indonesia.

Widarjono, A. (2015). Statistika Terapan Dengan Excel \& SPSS. Yogyakarta: UPP STIM YKPN.

Yuliani, T. (2015). Pertumbuhan Ekonomi dan Ketimpangan Pendapatan Antar Kabupaten di Kalimantan Timur. JEJAK Journal of Economics and Policy, 8(1), 1-88. 
Bidang Ilmu Pengetahuan Sosial 